Журнал«Герспективитаіновації наукиљ

(Серія «Гедагогіка», Серія«ГЕихологія», Серія«Медицина»

№1(6) 2022

УДК: 376.42

https://doi.org/10.52058/2786-4952-2022-1(6)-212-223

Косенко Юрій Миколайович кандидат педагогічних наук, доцент кафедри спеціальної та інклюзивної освіти, Сумський державний педагогічний університет імені А. С. Макаренка, вул. Інтернаціоналістів, 41/40, м. Суми, 40005, тел.: (050) 838-78-18, https://orcid.org/0000-0003-2723-2031

\title{
РОЗВИТОК СУСПІЛЬСТВОЗНАВЧОЇ ОСВІТИ ШКОЛЯРІВ 3 ІНТЕЛЕКТУАЛЬНИМИ ПОРУШЕННЯМИ В УКРАЇНІ В 90-ТІ РОКИ ХХ СТОЛІТТЯ
}

Анотація. У статті висвітлено комплексний історико-ретроспективний аналіз розвитку спеціальної методики навчання суспільствознавчим дисциплінам учнів з інтелектуальними порушеннями в Україні в 90-х роках минулого століття. Опрацьовано підручники суспільствознавчого змісту початку 90-х років за якими навчалися діти з порушеннями інтелектуального розвитку, здійснено аналіз навчальної програми 3 початкового курсу історії України для допоміжних шкіл, висвітлено особливості побудови та функціонування програми курсу «Методика викладання історії в допоміжній школі» для студентів дефектологічних факультетів педагогічних інститутів України, охарактеризовано навчальний посібник А. Капустіна та П. Ковтонюка «Методика викладання історії» для студентів-дефектологів і вчителів допоміжних шкіл.

Відзначено важливість підручника О. Кучерука «Оповідання 3 історії України» у формуванні суспільствознавчих уявлень і понять у школярів із порушеннями інтелекту. Підкреслено важливість появи в 1996 році навчальної програми 3 історії орієнтованої на пізнавальні можливості учнів 3 порушеннями інтелекту. Виділено концептуальні погляди авторів програми, які передбачали засвоєння такими школярами найбільш важливих фактів і подій в історії України, спрямованості змісту навчального курсу на формування загальнолюдських цінностей, залучення їх до надбань національної духовної та матеріальної культури.

Описано найбільш ефективні методи формування суспільствознавчих знань у дітей з інтелектуальними порушеннями того часу (розповідь вчителя, пояснююче читання тексту підручника та уривків художніх творів, бесіди, робота 3 адаптованими документами, виконання доступних завдань на історичній, територіально-адміністративній та контурній картах, робота 3 образною наочністю та інші).

Наголошено на важливості розділу «Основи правових знань» в межах курсу історії України в процесі вивчення якого, діти знайомилися з державним устроєм, основами адміністративного та кримінального права, що сприяло 
вихованню в учнів поваги до закону та формуванню соціально-нормативної поведінки.

Ключові слова: спеціальна освіта, учні з порушеннями інтелектуального розвитку, навчальний матеріал суспільствознавчого змісту, історикоретроспективний аналіз.

Kosenko Yuriy Mykolayovych Candidate of Pedagogical Sciences, Associate Professor of the Department of Special and Inclusive Education, Sumy State Pedagogical University named after AS Makarenko, Nternationalists St., 41/40, Sumy, 40005, tel.: (050) 838-78-18, https://orcid.org/0000-0003-2723-2031

\title{
DEVELOPMENT OF SOCIAL EDUCATION EDUCATION OF SCHOOLCHILDREN WITH INTELLECTUAL DISORDERS IN UKRAINE IN THE 90-S OF THE XX CENTURY
}

\begin{abstract}
The article highlights a comprehensive historical and retrospective analysis of the development of special methods of teaching social science disciplines to schoolchildren with intellectual disabilities in Ukraine in the 90s of last century. Textbooks of social science content of the early 90s were studied for children with intellectual disabilities, the curriculum of the primary course of Ukrainian history for auxiliary schools was analyzed, the peculiarities of construction and functioning of the course program «Methods of teaching history in auxiliary school» for students of special education pedagogical institutes of Ukraine, the textbook of A. Kapustin and P. Kovtonyuk «Methods of teaching history» for students of special education and teachers of auxiliary schools is described.

The importance of O. Kucheruk's textbook «Stories on the History of Ukraine» in the formation of social science ideas and concepts in schoolchildren with intellectual disabilities is noted. The importance of the emergence in 1996 of a history curriculum focused on the cognitive abilities of schoolchildren with intellectual disabilities was emphasized. The conceptual views of the authors of the program are highlighted, which provided for such schoolchildren to learn the most important facts and events in the history of Ukraine, the content of the course on the formation of universal values, their involvement in national spiritual and material culture.
\end{abstract}

The most effective methods of forming social science knowledge in children with intellectual disabilities of that time are described (teacher's story, explanatory reading of textbook text and excerpts from works of art, conversations, work with adapted documents, performing available tasks on historical, territorial and administrative and contour maps, working with figurative clarity and others).

Emphasis was placed on the importance of the section «Fundamentals of Legal Knowledge» within the course of Ukrainian history in the process of studying which, children learned about the state system, the basics of administrative and criminal law, which contributed to educating students to respect the law and social 
Журнал«Герстективита інновації наукиљ

(Серія «Гедагогіка», Серія «Гиихологія», Серія «Медицинв»

№(6) 2022

and normative behavior.

Keywords: special education, schoolchildren with intellectual disabilities, educational material of social science content, historical-retrospective analysis.

Постановка проблеми. Вивчення школярами суспільствознавства створює передумови для їхнього професійного самовизначення через знайомство 3 системою економічних, соціальних, політичних, історичних, національних, культурно-світоглядних, духовно-моральних та інших відносин.

$\mathrm{y}$ дітей $з$ порушеннями інтелектуального розвитку, початкові знання $\mathrm{i}$ уявлення суспільствознавчого характеру формуються переважно на уроках курсів «Історія України», «Основи правознавства», а також під час вивчення окремих тем i розділів корекційних занять 3 соціально-побутового орієнтування, української літератури та інших навчальних предметів.

Методика навчання предметам суспільствознавчого змісту має глибоке коріння й бере початок з позаминулого століття. Протягом багатьох десятиліть процес навчання суспільствознавству удосконалювався, з'являлися нові методи, прийоми й технології, впроваджувалися більш сучасні засоби й організаційно-педагогічні форми проведення таких занять. 3 появою інформаційно-комп'ютерних технологій цей процес став більш цікавим і ефективним $[1 ; 2 ; 3 ; 4]$.

Варто зауважити, що в роботі 3 дітьми, які мають інтелектуальні порушення, розлади аутистичного спектру або множинні порушення, не завжди результативними можуть бути заняття з використанням сучасних технологій. Провідну роль у цьому процесі відіграє вчитель, який враховує рівень інтелектуального, мовленнєвого, психофізичного та емоційного розвитку дитини, іiі мотивацію та інтерес до заняття.

На нашу думку, вивчення досвіду попередніх поколінь у процесі формування суспільствознавчих знань у дітей означеної категорії буде корисним. Історичний огляд наукових досліджень 90 -х років $\mathrm{XX}$ століття дозволить більш глибше зрозуміти методологію спеціальної дидактики, що $\epsilon$ важливим чинником у розробці новітніх підходів до навчання школярів із порушеннями інтелектуального розвитку предметам суспільствознавчого змісту.

Аналіз останніх досліджень і публікацій. Початок $90-\mathrm{x}$ років $\mathrm{XX}$ століття характеризуються розпадом СРСР та утворенням низки незалежних країн. У першій половині зазначеного хронологічного періоду продовжувалася тісна співпраця вчених-дефектологів 3 колишніх радянських республік. Результати досліджень науковців висвітлювалися, як в традиційній (що існували ще за часів СРСР) спеціалізованій періодиці та збірниках наукових праць, так і в новостворених національних виданнях («Дефектологія» (1995р.) та інші).

У 90-х роках минулого століття проблемою підвищення ефективності навчання й виховання дітей 3 порушеннями інтелектуального розвитку, 214 
розроблення змістового наповнення навчальних курсів для спеціальних закладів середньої освіти (допоміжних шкіл), удосконалення корекційнорозвиткового процесу в цих закладах займалися В. Бондар, Л. Вавіна, I. Єременко, М. Кот, Н. Кравець, Г. Мерсіянова, В. Синьов, М. Супрун. В. Товстоган та інші.

Досліджували вплив суспільствознавства на формування особистості школяра 3 порушеннями інтелекту, його вплив на соціалізацію та інтеграцію в суспільство, розробляли та впроваджували ефективні прийоми та засоби навчання дітей зазначеної категорії на уроках історії в спеціальних закладів середньої освіти такі науковці, як А. Кукура, А. Капустін, П. Ковтонюк, В. Лапшин, Г. Плешканівська, С. Попенко, Б. Пузанов, В. Ремажевська та інші.

У роботах науковців висвітлювалися переважно окремі методи та прийоми формування суспільствознавчих уявлень i понять у дітей 3 порушеннями інтелекту, описувалася технологія використання наочності на уроках історії, як провідного суспільствознавчого курсу в допоміжній школі, вказувалися найбільш ефективні прийоми формування хронологічних та просторових уявлень та їх корекції, пропонувалися перші варіанти навчальних програм у яких висвітлювалася національна історія, українські традиції, звичаї, культура, право тощо.

Мета статті - дослідження провідних методик та змістового наповнення навчальних курсів суспільствознавчого змісту для дітей 3 порушеннями інтелектуального розвитку в Україні в 90-х роках ХХ століття.

Виклад основного матеріалу. 24 серпня 1991 року Верховна Рада УРСР ухвалила Акт про проголошення незалежності України. У цей час найбільш актуальним постало завдання розроблення нового змістового наповнення курсів суспільствознавчого змісту для школярів 3 порушеннями інтелектуального розвитку, врахування тогочасних потреб і вимог суспільства, залучення дітей до вивчення минулого українського народу та творів заборонених радянською владою авторів (у випадку з учнями допоміжних шкіл - уривків зазначених творів), опрацювання адаптованих історичних документів тощо.

У галузі спеціальної освіти, Україна отримала в спадок від СРСР низку проблем, однією з яких було використання, по суті радянських навчальних програм та підручників, перекладених 3 російської мови. Зрозуміло, вони не сприяли втіленню в життя національної ідеї, вихованню патріотичних почуттів до України, любові до української історії, мови, літератури, поваги до культури, народних традицій і звичаїв.

Зауважимо, що на початковому етапі розбудови української держави та вітчизняної системи спеціальної освіти не існувало навчальної програми 3 курсу історії України та відповідних підручників.

Учителі історії допоміжних шкіл на власний розсуд переробляли навчальні програми до курсу «Вступ до історії України» для 5 класів загальноосвітніх закладів середньої освіти, спрощували навчальний матеріал, 
орієнтувалися на пізнавальні можливості учнів з порушеннями інтелекту.

Досліджуючи означену проблему, автор встановив, що в той час, низка вчителів історії орієнтувалися на навчальні програми з історії України для 7-9 класів масових шкіл (у 90-х роках XX століття курс «Оповідання 3 історії України» в допоміжних школах викладався у 7-9 класах). Зазначена категорія педагогів диференціювала тематику пропоновану для вивчення історії дітьми 3 нормо-типовим розвитком, враховувала індивідуальні можливості кожної дитини 3 порушеннями інтелектуального розвитку, матеріально-технічне забезпечення викладання історії в кожному навчальному закладі тощо.

Як бачимо, в перші роки незалежності України, викладання навчальних курсів суспільствознавчого змісту в допоміжних школах мало ознаки хаотичності. У той час ще не було розроблено спеціальних навчальних програм з курсів «Оповідання $з$ історії України», «Основи правознавства» та інших. Вчителі навчали дітей з порушеннями інтелекту на власний розсуд: за старими програмами, за переробленими програмами для 5 класів масових шкіл, за переробленими програмами для 7-9 класів загальноосвітніх закладів середньої освіти, за власними авторськими програмами [5].

Аналогічна ситуація склалася і з підручниками. Радянські підручники 3 історії СРСР були розроблені на іншій ідеологічній платформі, не відображали історичного минулого України і не враховували національного менталітету українців, тому не підходили для навчання дітей у незалежній Україні.

Наголосимо на тому, що шкільний курс історії в допоміжній школі був одним із провідних. На цих уроках дітей з порушеннями інтелекту знайомили у найбільш спрощеному варіанті 3 системою економічних, соціальних, політичних, історичних, національних, культурно-світоглядних, духовноморальних та інших відносин.

Яскравою ілюстрацією змісту та освітньо-корекційних можливостей курсу історії у допоміжній школі $\epsilon$ слова В. Лапшина і Б. Пузанова: «...допоміжна школа не ставить за мету дати учням систематизовані знання 3 історії. Курс історії у допоміжній школі будується на вивченні найбільш яскравих, значних подій вітчизняної історії, починаючи з первісного ладу i закінчуючи сучасними подіями у нашій країні та за кордоном. Курс історії передбачає вивчення елементів правового навчання учнів як одного із факторів їх соціальної адаптації. Також курсом історії передбачено певну роботу з краєзнавства» [6].

Починаючи 31992 року в допоміжних школах України в якості підручника 3 історії для 7-9-х класів використовували пробний підручник О. Кучерука «Оповідання 3 історії України» до початкового курсу 3 історії України для 5-го класу середньої школи». Ця навчальна книга на багато років стала основним посібником у вивченні історії школярами 3 порушеннями інтелекту.

Зауважимо, що створюючи цю книгу, О. Кучерук орієнтувався на інтелектуальні можливості школярів з нормо-типовим розвитком, тому вже 3 
перших сторінок роботи 3 цією книгою вчителям допоміжних шкіл потрібно було диференціювати навчальний матеріал, відбирати тільки головну й необхідну інформацію, використовувати додаткові ілюстрації, проводити словникову роботу тощо.

Структурно підручник складався з декількох частин: вступу, двох розділів та хронологічного довідника. Починаючи зі вступу автор знайомив школярів 3 такими поняттями, як «історія», «літопис», інформував давній східнослов'янський документ «Повість минулих літ» та його автора Нестора Літописця. Закінчувалися слова вступу надією на правдиве відношення до минулого нашої Батьківщини: «... у період, коли Україна була поневолена сильнішими сусідніми державами, було й таке, що окремі факти iï історії несправедливо замовчувалися, а то й зумисне викривлялися, а вірні сини України, які боролися за кращу долю своєї Батьківщини, оголошувалися іiі ворогами. Нині настав час розказати правдиву історію нашого народу, історію України» [7].

Як бачимо, починаючи зі вступу, змістове наповнення підручника мало низку складних для усвідомлення учнями з порушеннями інтелекту понять i категорій. У навчальних текстах першого розділу («Україна - незалежна держава») розміщувалася інформація, яка знайомила дітей з національною символікою, пояснювалося значення слова «Україна», повідомлявся рік першої згадки про Україну в історичних документах, розкривалося поняття «мала Батьківщина» тощо.

Другий розділ називався «Сторінки історії України» і складався з дев'яти тем, у яких висвітлювалося минуле нашої країни з найдавніших часів до 1991 року. У цьому розділі діти знайомилися з найбільш видатними й значними подіями в житті українського народу, вітчизняними історичними, державними та культурними діячами тощо.

Особливо актуальною для початку 90-х років минулого століття була остання тема другого розділу - «Сучасна Україна». У цій частині підручника, 3 національної, проукраїнської позиції автор розкривав діяльність Й. Сталіна, М. Хрущова, Л. Брежнєва, М. Горбачова, висвітлював стан економіки, господарства і культури в УРСР за часів їх керівництва. У параграфі «Ще не вмерла Україна» розповідалося про День Соборності, прийняття Декларації про суверенітет та проголошення Акту про незалежність України.

У кінці підручника О. Кучерука «Оповідання 3 історії України» було розміщено хронологічний довідник під назвою «Запам'ятайте ці дати». До нього ввійшли найбільш важливі дати з історії України з IX по XXI століття. Розпочинався довідник 988 роком - часом, коли було запроваджено християнство у Київській державі, а закінчувався 1991 роком - датою, коли розпався СРСР та проголошенням незалежності України [7].

Отже, на початку 90-х років XX століття підручник О. Кучерука «Оповідання 3 історії України» відіграв значну роль у формуванні суспільствознавчих уявлень і понять у школярів із порушеннями інтелекту. 
Журнал«Герспективитаінноваціїнауки

(Серія«Гедагогіка», Серія«ГЕихологія», Серія«Медицина»

№1(6) 2022

Підручник навіть для старшокласників 3 легкими порушеннями інтелектуального розвитку був складним за змістом, мав великий обсяг навчальної інформації, у ньому було недостатньо ілюстрацій, серед яких левова частка належала фотографіям.

Не дивлячись на те, що ця книга була розроблена в якості посібника до пропедевтичного курсу історії для учнів 5-х класів масової школи і не враховував пізнавальних можливостей школярів 3 інтелектуальними порушеннями 7-9-х класів, вона стала базовою для спеціальних закладів середньої освіти майже на десятиліття (перший, спеціально розроблений для дітей 3 порушеннями інтелекту підручник 3 історії був розроблений Г. Плешканівською та А. Слюсаренком у 2000 році).

У 1996 році Г. Плешканівська, В. Ремажевська, С. Попенко і А. Кукура розробили навчальну програму для допоміжної школи «Початковий курс історії України. 7-9 класи».

Структурно програма складалася 3 пояснювальної записки, переліку розділів і тем для 7-9 класів, вимог до знань і умінь учнів та списку рекомендованої літератури. Програма була адаптована до особливостей пізнавального розвитку школярів 3 порушеннями інтелекту i пропонувала викладати навчальний матеріал 3 історії України у певній системі, 3 дотриманням історичної хронології [8].

Групування матеріалу у 7-9 класах здійснювалося за такими розділами: «Україна - незалежна держава», «Україна в далекому минулому», «Київська держава», «Галицько-Волинська держава» (7 клас); «Подорож у козацькі часи», «Немає гірше, як в неволі...» (8 клас); «Від Української Народної Республіки до комуністичної диктатури», «Україна у вогні», «Сучасна Україна», «Основи правових знань» (9 клас).

Програмовий матеріал 3 розділу «Основи правових знань» знайомив дітей 3 конституційними правами громадян України, державним устроєм нашої Батьківщини та основами адміністративного та кримінального права, що сприяло вихованню в учнів поваги до закону та виробленню у них соціальнонормативної поведінки.

Аналіз навчальної програми дає можливості визначити найбільш актуальні для досліджуваного часу дидактичні методи i прийоми, засоби i підходи в навчанні дітей з порушеннями інтелекту темам суспільствознавчого змісту.

За програмою основним підходом у вивченні курсу історії у допоміжній школі вважалося пізнання важливих, суттєвих знань вітчизняної історії, які розкривають найбільш важливі сторінки суспільно-історичного процесу та пробуджують в учнів національну самосвідомість та гідність, формують у них громадянську позицію, знайомлять із загальнолюдськими цінностями.

Автори навчальної програми «Початковий курс історії України. 7-9 класи» пропонували вчителям історії враховувати малодоступність підручника О. Кучерука (навіть для учнів I відділення) та забезпечувати його якомога 218 
більшою кількістю коригуючих одиниць. Рекомендувалося вчителям будувати навчальний процес таким чином, щоб діти розв'язували інтелектуальні завдання, постійно узагальнювали вивчений на уроці матеріал i конкретизовували суспільно-історичні процеси відповідними подіями.

Необхідно відмітити дидактичні методи, які, на думку Г. Плешканівської, В. Ремажевської, С. Попенко і А. Кукури, є ефективними у навчанні історії дітей з порушеннями інтелекту.

У 90-х роках XX століття ефективними у вивчені суспільствознавчих тем вважалися такі методи, як розповідь вчителя, побудована за планом підручника, пояснююче читання тексту підручника та уривків художніх творів, бесіди на уроках історії, робота 3 адаптованими документами, виконання доступних завдань на історичній, територіально-адміністративній, фізичній та контурній картах.

Для унаочнення навчання перевага віддавалася роботі 3 історичними картинами, портретами, ілюстративним матеріалом, схемами, планами, картами, плакатами, діафільмами тощо.

Аналіз навчальної програми «Початковий курс історії України. 7-9 класи» свідчить про те, що в 90-ті роки минулого століття велика увага зверталася на формування у школярів 3 порушеннями інтелекту вмінь локалізовувати історичні факти у часі та просторі. Для цього викладався навчальний матеріал не лише у певній хронологічній послідовності, а й давалося чітке визначення часу виникнення історичної події.

Значна увага у досліджуваному періоді приділялася формуванню історико-просторових уявлень у дітей зазначеної категорії, засвоєнню ними історико-геграфічних понять.

Г. Плешканівська, В. Ремажевська, С. Попенко і А. Кукура рекомендували активно використовувати карти у навчанні історії: знаходити історикогеографічні об'єкти, правильно показувати та коментувати картографічний матеріал, поетапно й під контролем вчителя працювати 3 контурними картами. Завдання до контурних карт науковці пропонували вчителям розробляти самостійно, з урахуванням «зони актуального розвитку» та «зони найближчого розвитку» в дітей з порушеннями інтелекту. На думку вчених, більшість завдань, які пропонувалися в контурних картах (у допоміжних школах використовували історичні атласи та контурні карти 3 історії для 5 класів масової школи) є складними для школярів 3 порушеннями інтелекту і не підходять для них.

Актуальним для 90-х років $\mathrm{XX}$ століття при вивченні тем суспільствознавчого змісту було систематичне повторення вивченого матеріал у різноманітних видах i формах. Завдяки цьому відбувалося уточнення суспільствознавчих знань і усвідомлення навчального матеріалу школярами зазначеної категорії.

Отже, перша вітчизняна навчальна програма до суспільствознавчого курсу «Початковий курс історії України. 7-9 класи» для допоміжних шкіл 
враховувала пізнавальні можливості учнів з порушеннями інтелектуального розвитку. Навчальний матеріал відображав найбільш важливі віхи історії України, вивчення яких формувало в школярів означеної категорії загальнолюдські цінності, прилучало їх до надбань національної духовної та матеріальної культури.

Важливе значення для розвитку спеціальної методики навчання суспільствознавчим дисциплінам мали методичні рекомендації, які надали науковці вчителям-практикам. Вчені рекомендували в навчанні дітей 3 інтелектуальними порушеннями давати завдання в різних варіаціях на розвиток мислення, підводити дітей до певних узагальнень, проводити словникову роботу, при поясненні суспільно-історичних процесів наводити конкретні приклади, залежно від контингенту учнів і навчального матеріалу використовувати стислу або розгорнуту розповідь, застосовувати бесіди, пояснююче читання навчальних текстів, використовувати наочність тощо.

Значний внесок у розвиток спеціальної методики навчання предметам суспільствознавчого змісту здійснили А. Капустін, П. Ковтонюк, Б. Пузанов. Дослідниками було розроблено зміст програми курсу «Методика викладання історії в допоміжній школі» для студентів дефектологічних факультетів педагогічних інститутів України. Ця програма передбачала формування теоретичних знань і практичних умінь у майбутніх вчителів-дефектологів для успішного навчання історії та основам правознавства школярів з порушеннями інтелекту в допоміжних школах [9].

За програмою, студенти на лекціях знайомилися 3 предметом i завданнями курсу, з навчально-виховними і корекційними цілями вивчення історії, специфікою навчання школярів із порушеннями інтелекту, особливостями засвоєння історичних знань учнями допоміжних шкіл. Також у здобувачів освіти формувалися уміння використовувати першоджерела та документальні матеріали для планування і проведення уроків історії.

На початку 90-х років XX століття, відповідно до змісту програми 3 методики викладання історії у допоміжній школі, А. Капустіним i П. Ковтонюком було розроблено навчальний посібник для студентівдефектологів та вчителів допоміжних шкіл «Методика викладання історії». У цій книзі здійснено спробу узагальнення результатів науково-дослідницької роботи науковців та передового досвіду вчителів-практиків, розкрито завдання навчання історії, зв'язок навчання історії з іншими навчальними предметами, висвітлено труднощі та особливості формування історичних i суспільствознавчих понять у дітей з порушеннями інтелекту, описано форми і методи навчання історії з урахуванням особливостей психофізичного розвитку та потенційних можливостей учнів допоміжної школи, наведено схеми історичного та суспільствознавчого матеріалу, який викладається у допоміжній школі у рамках курсу історії [10].

Отже, великий вплив на розвиток суспільствознавчої освіти школярів 3 інтелектуальними порушеннями в Україні в 90-ті роки XX століття та 
становлення високопрофесійної плеяди вчителів-дефектологів мали праці А. Капустіна, П. Ковтонюка та Б. Пузанова.

Висновки. Підсумовуючи стан формування суспільствознавчих знань у дітей із порушеннями інтелектуального розвитку в Україні в 90-х роках минулого століття зауважимо, що провідним навчальним предметом, на якому діти засвоювали суспільствознавчі поняття та формували відповідні предметні вміння був курс історії України.

У перші роки незалежності нашої держави, навчання історії школярів 3 інтелектуальними порушеннями відбувалося за старими підручниками та програмами або самостійно адаптованими програмами, які вже були розроблені для масових шкіл. Першим підручником з історії України, за яким навчалися учні допоміжних шкіл, був підручник О. Кучерука «Оповідання 3 історії України». Підручник О. Кучерука був розроблений для учнів 5-х класів загальноосвітніх шкіл. Ця книга не була адаптована до пізнавальних можливостей учнів з інтелектуальними порушеннями, але іiі зміст стосувався минулого нашої країни та повністю відповідав національним інтересам i вимогам українського суспільства.

Навчальна програма до курсу історії для допоміжних шкіл з'явилися в 1996 році й була орієнтована на засвоєння учнями найбільш важливих фактів в історії українського народу та знайомство дітей із діяльністю видатних українських діячів у сфері державного управління, культури, освіти і науки.

Підвищенню ефективності вивченню тем суспільствознавчого змісту сприяв виданий А. Капустіним і П. Ковтонюком навчальний посібник для студентівдефектологів та вчителів допоміжних шкіл «Методика викладання історії».

Таким чином, на початковому етапі розбудови вітчизняної системи спеціальної освіти продовжувався процес удосконалення методів навчання та забезпечення змістового наповнення курсів історії України для 7-9 класів та розділу «Основи правових знань» (у межах цього навчального предмету).

\section{Jimepamypa:}

1. Косенко Ю. М. Ретроспектива шляхів підвищення ефективності навчання історії дітей із порушеннями інтелекту: 70-ті роки ХХ століття / Ю. М. Косенко, О. В. Боряк // Педагогіка формування творчої особистості у вищій і загальноосвітній школах: збірник наукових праць. Запоріжжя: КПУ, 2020. Вип. 73. Т. 1. С. 28-33.

2. Косенко Ю. М. Застосування комп'ютерних дидактичних ігор у навчанні історії школярів з порушеннями інтелектуального розвитку в умовах інклюзивного класу / Ю. М. Косенко, О. В. Боряк, О. М. Король // Інформаційні технології і засоби навчання. 2020. Т. 77. № 3. С. 76-89.

3. Косенко Ю. М. Розвиток правової освіти дітей з порушеннями інтелектуального розвитку в Україні з початку ХХ століття до 1991 року / Ю. М. Косенко // Збірник наукових праць Кам'янець-Подільського національного університету імені Івана Огієнка. Серія : соціально-педагогічна. Кам’янець-Подільський, 2020. Вип. XXXIV. С. 102-112.

4. Косенко Ю. М. Підвищення ефективності навчання історії учнів із порушеннями інтелектуального розвитку / Ю. М. Косенко // Корекційно-реабілітаційна діяльність у сучасному освітньому просторі: монографія. Суми : Вид-во СумДПУ імені А. С. Макаренка, 2019. С. 55-70. 
5. Косенко Ю. М. Становлення та розвиток спеціальної методики навчання історії (друга половина XIX - початок XXI століть) : монографія. / Ю. М. Косенко. - Чернівці : Букрек, 2016. - $216 \mathrm{c}$.

6. Лапшин В. А. Основы дефектологии / В. А. Лапшин, Б. П. Пузанов. - М. : Просвещение, 1991. - 143 с.

7. Кучерук О. С. Оповідання з історії України. Пробний підручник до початкового курсу історії України для 5 класу середньої школи / О. С. Кучерук. - К. : Освіта, 1993. $240 \mathrm{c}$.

8. Плешканівська Г. М. Програми допоміжної школи. Початковий курс історії України : 7-9 класи / Г. М. Плешканівська, С. А. Попенко, В. М. Ремажевська, А. І. Кукура. - К. : ВІПОЛ, 1996. - 22 с.

9. Капустін А. І. Програма курсу «Методика навчання історії в допоміжній школі»// А. І. Капустін, Б. П. Пузанов, П. С. Ковтанюк. - К. : РУМК, 1991. - 28 с.

10. Капустин А. И. Методика преподавания истории. Учебное пособие для студентов-дефектологов и учителей вспомогательных школ / А. И. Капустин, П. Е. Ковтонюк. - Славянск : СГПИ, 1992. - 115 с.

\section{References:}

1. Kosenko, Yu. M., \& Boriak, O. V. (2020). Retrospektyva shliakhiv pidvyshchennia efektyvnosti navchannia istorii ditei iz porushenniamy intelektu: 70-ti roky XX stolittia [A retrospective of ways to increase the effectiveness of teaching the history of children with intellectual disabilities: the 70s of the twentieth century]. Pedahohika formuvannia tvorchoi osobystosti $u$ vyshchii $i$ zahalnoosvitnii shkolakh: zbirnyk naukovykh prats - Pedagogy of formation of creative personality in higher and secondary schools: a collection of scientific works, 73, Vol. 1, 28-33 [in Ukrainian].

2. Kosenko, Yu. M., \& Boriak, O. V., \& Korol O. M. (2020). Zastosuvannia kompiuternykh dydaktychnykh ihor $\mathrm{u}$ navchanni istorii shkoliariv $\mathrm{z}$ porushenniamy intelektualnoho rozvytku $\mathrm{v}$ umovakh inkliuzyvnoho klasu [Application of computer didactic games in teaching the history of schoolchildren with intellectual disabilities in an inclusive classroom]. Informatsiini tekhnolohii $i$ zasoby navchannia - Information technologies and teaching aids, Vol. 77, 3, 76-89 [in Ukrainian].

3. Kosenko, Yu. M. (2020). Rozvytok pravovoi osvity ditei z porushenniamy intelektualnoho rozvytku v Ukraini z pochatku XX stolittia do 1991 roku [Development of legal education of children with intellectual disabilities in Ukraine from the beginning of the XX century to 1991]. Zbirnyk naukovykh prats Kamianets-Podilskoho natsionalnoho universytetu imeni Ivana Ohiienka. Seriia : sotsialno-pedahohichna - Collection of scientific works of Kamyanets-Podilsky National University named after Ivan Ogienko. Series: socio-pedagogical, XXXIV, 102-112 [in Ukrainian].

4. Kosenko, Yu. M. (2019). Pidvyshchennia efektyvnosti navchannia istorii uchniv iz porushenniamy intelektualnoho rozvytku [Improving the effectiveness of teaching history to students with intellectual disabilities]. Korektsiino-reabilitatsiina diialnist $u$ suchasnomu osvitnomu prostori: monohrafiia - Correctional and rehabilitation activities in modern educational space: monograph. 55-70 [in Ukrainian].

5. Kosenko, Yu. M. (2016). Stanovlennia ta rozvytok spetsialnoi metodyky navchannia istorii (druha polovyna XIX - pochatok XXI stolit) [Formation and development of special methods of teaching history (second half of the XIX - early XXI centuries)]. Chernivtsi: Bukrek. [in Ukrainian].

6. Lapshin, V. A., \& Puzanov, B. P. (1991). Osnovy defektologii [Fundamentals of defectology]. Moscow: Prosveshchenie. [in Russia]. 
7. Kucheruk, O. S. (1993). Opovidannia z istorii Ukrainy. Probnyi pidruchnyk do pochatkovoho kursu istorii Ukrainy dlia 5 klasu serednoi shkoly [Stories from the history of Ukraine. Probnyi pidruchnyk do pochatkovoho kursu istorii Ukrainy dlia 5 klasu serednoi shkoly]. Kyiv: Osvita. [in Ukrainian].

8. Pleshkanivska, H. M., \& Popenko, S. A., \& Remazhevska, V. M., \& Kukura, A. I. (1996). Prohramy dopomizhnoi shkoly. Pochatkovyi kurs istorii Ukrainy: 7-9 klasy [Auxiliary school programs. Initial history course of Ukraine: 7-9 classes]. Kyiv: VIPOL. [in Ukrainian].

9. Kapustin, A. I., \& Puzanov, B. P., \& Kovtaniuk, P. E. (1991). Prohrama kursu «Metodyka navchannia istorii v dopomizhnii shkoli» [Course program «Methods of teaching history in the auxiliary school»]. Kyiv: RUMK. [in Ukrainian].

10. Kapustin, A. I., \& Kovtaniuk, P. E. (1992). Metodika prepodavaniya istorii. Uchebnoe posobie dlya studentov-defektologov i uchitelej vspomogatel'nyh shkol [Methods of teaching history. A textbook for students-defectologists and teachers of auxiliary schools]. Slavyansk: SGPI. [in Ukrainian]. 